\title{
Recombinant Human Epo Treatment: Beneficial in Chronic Kidney Disease, Chronic Heart Failure, or Both?
}

\author{
Editorial to: "Correction of Anemia with Erythropoietin in Chronic Kidney Disease \\ (Stage 3 or 4): Effects on Cardiac Performance by Pappas et al."
}

\author{
A. M. S. Belonje • R. A. de Boer • A. A. Voors
}

Published online: 25 January 2008

(C) The Author(s) 2008

For over two decades now, the recombinant form of erythropoietin (RhEPO) is used for the treatment of anemia in end-stage renal disease patients. Initial studies indicated an improvement in quality of life [1]. However, neutral/ negative data from two randomized controlled trials testing $\mathrm{RhEPO}$ to correct anemia in chronic kidney disease (CKD) were recently reported $[2,3]$. The CHOIR study evaluated the effects of achieving high $\mathrm{Hb}$ levels $(13.5 \mathrm{~g} / \mathrm{dl})$ compared to lower $\mathrm{Hb}$ levels $(11.3 \mathrm{~g} / \mathrm{dl})$ on cardiovascular complications in CKD patients with an eGFR $\leq 50 \mathrm{ml} / \mathrm{min} /$ $1.73 \mathrm{~m}^{2}$. This study was prematurely halted, because of an increased adverse event rate in the high $\mathrm{Hb}$ group [2]. The CREATE study evaluated the effect of complete $\mathrm{Hb}$ correction $(13.0$ to $15.0 \mathrm{~g} / \mathrm{dl})$ to lower hemoglobin $(\mathrm{Hb})$ correction $(10.5-11.5 \mathrm{~g} / \mathrm{dl})$ in CKD patients with an eGFR $<35 \mathrm{ml} / \mathrm{min} / 1.73 \mathrm{~m}^{2}$. In these patients complete correction of $\mathrm{Hb}$ did not change the risk on cardiovascular events [3]. So, both studies failed to demonstrate a better survival by correcting $\mathrm{Hb}$ levels to normal values, although both studies had an open-label design and were not placebocontrolled. Currently, a large, randomized, placebo-controlled, double blind trial to evaluate the effect of RhEPO treatment (to achieve $\mathrm{Hb}$ levels of $13.0 \mathrm{~g} / \mathrm{dl}$ ) on cardiovascular events in anemic CKD patients (TREAT) is ongoing [4]. A recent statement from the DSMB conveyed no evidence for terminating the TREAT study. Of note, this analysis was based on more endpoints than both CREATE and CHOIR together.

\footnotetext{
A. M. S. Belonje · R. A. de Boer · A. A. Voors $(\bowtie)$

Department of Cardiology, Thoraxcenter,

University Medical Center Groningen, University of Groningen,

Hanzeplein 1,

9700 RB Groningen, The Netherlands

e-mail: A.A.Voors@thorax.umcg.nl
}

In contrast to studies in CKD patients, two recent randomized, double-blind, placebo controlled studies with anemic chronic heart failure (CHF) patients consistently indicated beneficial cardiovascular and quality of life effects of RhEPO treatment $[5,6]$. The first study by Ponikowski et al. [5] included 41 anemic CHF patients who were randomly assigned to either receive darbepoetin-alpha or placebo for 26 weeks to reach a target $\mathrm{Hb}$ of $13-15 \mathrm{~g} / \mathrm{dl}$. $\mathrm{RhEPO}$ increased $\mathrm{Hb}$ and in the treatment group, quality of life improved and a trend towards exercise duration was observed. In another study, van Veldhuisen et al. [6] evaluated the effect of weight-based and fixed starting dose $\mathrm{RhEPO}$ treatment compared to placebo in 165 anemic CHF patients. After 26 weeks, both RhEPO groups showed similar effects on $\mathrm{Hb}$ concentrations and this was associated with an improvement in quality of life. Importantly, both studies showed no difference in the incidence of adverse events. Thus, results from studies executed primarily in anemic $C K D$ patients (neutral/negative) contrasted with results from studies executed primarily in anemic $\mathrm{CHF}$ patients (mainly positive). Notably, only $32 \%$ of the patients in CREATE and $24 \%$ in CHOIR had signs of heart failure. Alternatively, only the minority of anemic CHF patients had an eGFR $<35-50 \mathrm{ml} / \mathrm{min} / 1.73 \mathrm{~m}^{2}$. So, there was little overlap between patient groups in these studies.

Therefore, the study by Pappas et al. [7] in this present issue of Cardiovascular Drugs and Therapy is particularly interesting, because it brings both worlds together. They aimed to determine the effects of RhEPO (targeting at $\mathrm{Hb} \geq 13.0 \mathrm{~g} / \mathrm{dl}$ ) on cardiac structure and function in patients with CKD. Although systolic left ventricular function was generally normal, diastolic dysfunction and left ventricular hypertrophy was already present in a large number of patients. They demonstrated that RhEPO treatment resulted 
in a marked improvement in both systolic and diastolic left ventricular function, and a reduction in left ventricular mass Their results support the beneficial effects of long term RhEPO treatment on cardiac function and structure in anemic patients with CKD and evidence of cardiac dysfunction.

Is there an explanation for this observation? The generally positive effects of RhEPO in CHF patients, but not in CKD patients, suggests differential effects of RhEPO in these two patient groups. To appreciate this, we need to look into the mechanisms by which RhEPO exerts its effects. We performed several experimental studies to elucidate the working mechanism of RhEPO.

Different from the general concept, we (and others) have shown that the beneficial cardiovascular effects of RhEPO are not related to the increase in $\mathrm{Hb}$. The effects are rather conferred by extra-hematopoietic effects, independent from anemia correction. In a study by Lipsic et al. [8] a low dose of EPO did not stimulate erythropoiesis, but did have the same positive effects on left ventricular function and angiogenesis. Carbamylated EPO (CEPO), which lacks erythropoietic activity, shows similar results compared to RhEPO in the protection of myocardial tissue [9]. The discovery of the presence of the EPO receptor (EPO-R) in the myocardium and endothelium provided new perspectives on the function of EPO besides stimulating erythropoiesis. First, it withholds myocardial cells from apoptosis and thereby opposes cardiac remodeling. This anti-apoptotic effect was found in multiple animal ischemia-reperfusion models in which treatment with EPO resulted in a smaller infarct size and an enhanced cardiac performance [10-12]. In addition, we recently reported that a bolus of RhEPO in patients with an acute myocardial infarction was safe and feasible [13], and a larger randomized, clinical efficacy trial is currently ongoing (ClinicalTrials.gov number: NCT00449488). Second, RhEPO treatment in a CHF rat model stimulates angiogenesis and neovascularisation, which improves myocardial blood flow. Our group showed that in an experimental rat MI model, EPO treatment not only recruits endothelial progenitor cells (EPC)s from the bone marrow, but also demonstrated that these EPCs also home to and incorporate in myocardial capillaries to form new vessels [14]. Because of the experimental favorable effects on the injured myocardium, these extra-hematopoietic effects of EPO are of great interest in the treatment of patients with heart failure.

So, the study by Pappas et al. [7] demonstrated that beneficial effect of RhEPO on cardiac structure and function are also found in patients with CKD. We believe that the cardioprotective effects of RhEPO are mainly caused by decreasing apoptosis and by stimulating new vessel formation and by a lesser degree through its stimulation of erythropoiesis Whether these findings will translate into reduction of mortality and morbidity is currently under investigation in the RED-HF trial (ClinicalTrials.gov number: NCT00358215).

Open Access This article is distributed under the terms of the Creative Commons Attribution Noncommercial License which permits any noncommercial use, distribution, and reproduction in any medium, provided the original author(s) and source are credited.

\section{References}

1. Jones M, Ibels L, Schenkel B, Zagari M. Impact of epoetin alfa on clinical end points in patients with chronic renal failure: a metaanalysis. Kidney Int 2004;65:757-67.

2. Singh AK, Szczech L, Tang KL, et al. Correction of anemia with epoetin alfa in chronic kidney disease. N Engl J Med 2006;355:2085-98.

3. Drueke TB, Locatelli F, Clyne N, et al. Normalization of hemoglobin level in patients with chronic kidney disease and anemia. N Engl J Med 2006;355:2071-84.

4. Pfeffer MA. An ongoing study of anemia correction in chronic kidney disease. N Engl J Med 2007;356:959-61.

5. Ponikowski P, Anker SD, Szachniewicz J, et al. Effect of darbepoetin alfa on exercise tolerance in anemic patients with symptomatic chronic heart failure: a randomized, double-blind, placebo-controlled trial. J Am Coll Cardiol 2007;49:753-62.

6. van Veldhuisen DJ, Dickstein K, Cohen-Solal A, et al. Randomized, double-blind, placebo-controlled study to evaluate the effect of two dosing regimens of darbepoetin alfa in patients with heart failure and anaemia. Eur Heart J 2007;28:2208-16.

7. Pappas KD, Gouva CD, Katopodis KP, et al. Correction of anemia with erythropoietin in chronic kidney disease (stage 3 or 4): effects on cardiac performance. Cardiovasc Drugs Ther. 2007; DOI 10.1007/s10557-007-6075-6.

8. Lipsic E, Westenbrink B, van der Meer P, et al. Low-dose erythropoietin improves cardiac function in experimental heart failure without increasing haematocrit. Eur J Heart Fail. 2007; in press (December 10).

9. Fiordaliso F, Chimenti S, Staszewsky L, et al. A nonerythropoietic derivative of erythropoietin protects the myocardium from ischemiareperfusion injury. Proc Natl Acad Sci U S A 2005;102:2046-51.

10. van der Meer P, Lipsic E, Henning RH, et al. Erythropoietin induces neovascularization and improves cardiac function in rats with heart failure after myocardial infarction. J Am Coll Cardiol $2005 ; 46: 125-33$.

11. Lipsic E, van der Meer P, Henning RH, et al. Timing of erythropoietin treatment for cardioprotection in ischemia/reperfusion. J Cardiovasc Pharmacol 2004;44:473-9.

12. van der Meer P, Lipsic E, Henning RH, et al. Erythropoietin improves left ventricular function and coronary flow in an experimental model of ischemia-reperfusion injury. Eur $\mathrm{J}$ Heart Fail 2004;6:853-9.

13. Lipsic E, van der Meer P, Voors AA, Westenbrink BD, van den Heuvel AF, de Boer HC, van Zonneveld AJ, Schoemaker RG, van Gilst WH, Zijlstra F, van Veldhuisen DJ. A single bolus of a long-acting erythropoietin analogue darbepoetin alfa in patients with acute myocardial infarction: a randomized feasibility and safety study. Cardiovasc Drugs Ther 2006;20:135-41.

14. Westenbrink BD, Lipsic E, van der Meer P, et al. Erythropoietin improves cardiac function through endothelial progenitor cell and vascular endothelial growth factor mediated neovascularization. Eur Heart J 2007;28:2018-27. 